\title{
Association Between Bifurcation Angle and Coronary No-reflow Following Primary Percutaneous Coronary Intervention in Patients
}

\author{
Primer Perkutan Koroner Girişim Sonrası Hastalarda Bifurkasyon Açısı \\ ile Koroner No-reflow Arasındaki İlişki
}

\section{(D) Ömer Taşbulak1, (D) Mustafa Duran², (D) Ahmet Anıl Şahin³, (D) Ali Rıza Demir1, (D Recep Gülmez¹, (D) Mehmet Ertürk1, (D Mehmet Emin Kalkan4}

\author{
${ }^{1}$ University of Health Sciences Turkey, İstanbul Mehmet Akif Ersoy Thoracic and Cardiovascular Surgery Training and Research Hospital, Clinic \\ of Cardiology, İstanbul, Turkey \\ 2Konya Training and Research Hospital, Clinic of Cardiology, Konya, Turkey \\ 3̇̇stinye University, Liv Bahçeşehir Hospital, Clinic of Cardiology, İstanbul, Turkey \\ 4University of Health Sciences Turkey, Başahşehir Çam ve Sakura City Hospital, Clinic of Cardiology, İstanbul, Turkey
}

\section{Abstract}

Objective: Percutaneous coronary intervention (PCI) has become the treatment method for patients presenting with ST elevation myocardial infarction (STEMI). One of the well-known complications of $\mathrm{PCl}$ is no-reflow. Studies demonstrated a relationship between endothelial dysfunction and disturbed vascular flow due to angulation of vascular tree. Although the relationship between hemodynamic alterations and coronary angulation is evident, there is a lack of detailed analysis in terms of hemodynamic changes between vascular geometry and coronary no-reflow. We aimed to elucidate the relationship between vascular geometry and coronary no-reflow.

Method: We reviewed $\mathrm{PCl}$ database of our hospital and enrolled a total of 120 patients with STEMI, who developed no-reflow following $\mathrm{PCl}$, and sex and age matched 80 patients with normal flow. For each group, demographic and clinical characteristics, laboratory values and two dimensional quantitative coronary angiography measurements were evaluated.

Results: Patients with no-reflow had a higher prevalence of hypertension and diabetes mellitus. In addition, serum C-reactive protein levels were higher in patients with no-reflow compared to patients with normal flow $(p<0.001)$. On the other hand, serum hemoglobin levels were significantly lower in patients with no-reflow compared to patients with normal flow $(p<0.001)$. With respect to 3 dimensional coronary measurements, calculated bifurcation angle of left anterior descending artery (LAD) and

\section{Öz}

Amaç: Perkutan koroner girişim (PKG), ST yükselmeli miyokard enfarktüsü (STYMI) ile başvuran hastalarda tedavi yöntemidir. PKG'nin en iyi bilinen komplikasyonlarından biri, no-reflow'dur. Çalışmalar, endotel disfonksiyonu ile vasküler yapı angulasyonu nedeniyle bozulmuş vasküler akış arasındaki ilişkiyi göstermiştir. Hemodinamik değişiklikler ile koroner açılanma arasındaki ilişki hakkında bilgimiz olsa da, vasküler geometri ile koroner akım arasındaki hemodinamik değişiklikler açısından ayrıntılı bir analiz eksikliği vardır. Vasküler geometri ile koronerde no-reflow arasındaki ilişkiyi aydınlatmayı amaçladık.

Yöntem: Hastanemizin PKG veri tabanını gözden geçirdik ve PKG'yi takiben no-reflow gelişen ve buna ek olarak cinsiyet ve yaşı eşleşen 80 normal akım olan hastayı 120 STYMI hastasını kaydettik. Her grup için demografik ve klinik özellikler, laboratuvar değerleri ve iki boyutlu kantitatif koroner anjiyografi ölçümleri değerlendirildi.

Bulgular: No-reflow hastalarda daha yüksek hipertansiyon ve diabetes mellitus prevalansı vardı. Ek olarak, serum C-reaktif protein seviyeleri, normal akışa sahip hastalara kıyasla no-reflow gelişen hastalarda daha yüksekti $(p<0,001)$. Öte yandan, serum hemoglobin seviyeleri, normal akışa sahip hastalara kıyasla, no-reflow gelişen hastalarda anlamlı olarak daha düşüktü $(p<0,001)$. Üç boyutlu koroner ölçümlere göre, sol ön inen arter (LAD) ve sirkumfleks arterin (CX) hesaplanan çatallanma açıSI, kontrol grubuna göre no-reflow grubunda anlamlı olarak daha genişti $\left[110,9^{\circ}\left(21,8^{\circ}\right)\right.$ vs. $\left.85,9^{\circ}\left(15,8^{\circ}\right), p<0,001\right]$

Address for Correspondence: Ahmet Anıl Şahin, İstinye University, Liv Bahçeşehir Hospital, Clinic of Cardiology, İstanbul, Turkey E-mail: aanilsahin@hotmail.com ORCID: orcid.org/0000-0003-1956-2348 Received: 10.04.2021 Accepted: 27.09.2021

Cite this article as: Taşbulak Ö, Duran M, Şahin AA, Demir AR, Gülmez R, Ertürk M, Kalkan ME. Association Between Bifurcation Angle and Coronary No-reflow Following Primary Percutaneous Coronary Intervention in Patients. Bagcilar Med Bull 2021;6(4):361-369

${ }^{\odot}$ Copyright 2021 by the Health Sciences University Turkey, Bagcilar Training and Research Hospital Bagcilar Medical Bulletin published by Galenos Publishing House. 


\section{Abstract}

circumflex artery $(C X)$ was significantly wider in the no-reflow group than in the control group [110.9 $\left(21.8^{\circ}\right)$ vs. $\left.85.9^{\circ}\left(15.8^{\circ}\right), p<0.001\right]$.

Conclusion: Our data showed that a strong association existed between bifurcation angle of LAD-CX and no-reflow phenomenon in STEMI patients who underwent $\mathrm{PCl}$.

Keywords: Bifurcation angle, no reflow, percutaneous coronary intervention

\section{Öz}

Sonuç: Verilerimiz, PKG uygulanan STYMI hastalarında LAD-CX'in bifurkasyon açısı ile no-reflow fenomeni arasında güçlü bir ilişki olduğunu gösterdi.

Anahtar kelimeler: Bifurkasyon açısı, no-reflow, perkutan koroner girişim

\section{Introduction}

Percutaneous coronary intervention (PCI) is the preferred method for revascularization in patients presenting with ST elevation myocardial infarction (STEMI) (1). Because of effective and immediate blood flow restoring in infarct related artery (IRA), its use has increased noteworthy over the past decades (2). However, PCI is not always associated with good clinical outcomes because of possible complications. One of the well-known complications of PCI is no-reflow phenomenon $(3,4)$.

Previous studies have shown that incidence of no-reflow phenomenon ranged from $2 \%$ to $44 \%$ among patients who underwent primary or elective PCI and mortality rate ranged from 7.4 to $30.3 \%$ in these patient populations (412). The term "no-reflow phenomenon" is described as disturbance of myocardial perfusion throughout a specified segment of coronary circulation without any angiographic evidence of coronary artery obstruction, spasm, or dissection (4,9). Although this condition is generally diagnosed by using coronary angiography, myocardial contrast echocardiography is the gold standard method for the diagnosis of no-reflow phenomenon $(10,11)$. Underlying factors contributing to the development of no-reflow phenomenon were described as distal atherothrombotic embolization, ischemic injury, reperfusion injury, and oxidative stress (13). This condition also is associated with adverse cardiac events including re-myocardial infarction, reduced left ventricular function, left ventricular remodeling, cardiac arrhythmias, and death (11). However, there is no definite treatment strategy for this phenomenon $(14,15)$. Owing to afore-mentioned difficulties, it is essential to determine predictive risk factors for coronary no-reflow.

Laminar shear stress is the major pathophysiologic factor for progression, generation and destabilization on atherosclerotic plaques (16). Bifurcation sites of coronary arteries are more prone to the disruption of laminar blood flow and when laminar blood flow is disrupted, an atheroprone environment tends to occur. This pathophysiologic process have also been shown by recent studies that most of the atherosclerotic plaques form close to the bifurcation sites of the coronary arteries and strongly associated with vascular geometry $(17,18)$. Although hemodynamic alterations due to various coronary artery angulations are strongly associated with atherosclerosis, there is a lack of detailed analysis in terms of hemodynamic changes in relation to vascular geometry and coronary noreflow phenomenon.

Therefore, the aim of this study was to evaluate the relationship between vascular geometry and coronary noreflow phenomenon.

\section{Materials and Methods}

\section{Study Population}

We reviewed the PCI database of our hospital and enrolled a total of 120 patients with acute STEMI, who developed noreflow phenomenon following primary PCI between January 2019 and January 2020 and a total of age and sex matched 80 patients with acute STEMI in whom the no-reflow did not occur following primary PCI between November 2019 and January 2020. Acute STEMI was defined based on criteria by the European Society of Cardiology (19). All the patients were either presented with left anterior descending (LAD) or circumflex (CX) artery occlusion in the clinical aspect of STEMI and PCI was performed to the IRA. Demographic and clinical characteristics of patients and indication for the procedure were retrospectively analyzed. Patients with poor image quality, history of end-stage renal failure, liver failure, coagulopathy, malignancy, inflammatory disease, cardiogenic shock and pregnancy were excluded from the study. Patients who underwent primary PCI after 12 hours from the onset of symptoms and patients who underwent rescue PCI were also excluded. Informed consent was obtained from all patients in accordance with a protocol approved by local ethics committee. 


\section{Procedure}

Coronary angiography was performed in 90 min following hospital admission. PCI procedures were performed via femoral or radial arterial access using 6 French (F) or $7 \mathrm{~F}$ sheaths. All patients were treated with dual antiplatelet therapy including loading dose of aspirin (162-325-mg orally) in addition to loading doses of clopidogrel (600 $\mathrm{mg}$ orally) or prasugrel (60 mg orally) or ticagrelor (180 $\mathrm{mg}$ orally) prior to the procedure. Intravenous heparin was administered to achieve an activated clotting time of 300s. Adjunctive pharmacotherapies, type of stent, use of pre-dilatation and post-dilatation were at the discretion of the interventional cardiologist. Epicardial coronary blood flow was quantified visually using the thrombolysis in myocardial infarction (TIMI) flow grade classification (20). Procedural success was defined as residual stenosis $<20 \%$ and TIMI flow grade 3. Intracoronary injection of verapamil, adenosine and GP IIb/IIIa inhibitor were administered when no-reflow was observed. All patients underwent preand post-intervention electrocardiography and evaluated by cardiologist blinded to the assignment protocol.

\section{Assessment of Coronary Angiograms}

Initial TIMI flow was assessed at the beginning of the procedure prior to wire insertion and final TIMI flow was assessed at the end of the procedure. We also assessed coronary flow immediately before and after stent insertion by using myocardial blush grading (MBG) (21). According to our study, no reflow was defined as TIMI flow $<3$ (with any MBG grade) or TIMI flow 3 with MBG 0 or 1 at the end of the procedure in the absence of any coronary dissection or spasm. Depending on their final coronary flow status, patients were assigned to one of two groups; no-reflow occurred group (120 patients) and sex and age matched normal flow group (80 patients).

The bifurcation angles of the left main coronary artery (LMCA) - LAD, LMCA-CX and LAD-CX were measured by using three dimensional quantitative coronary angiography (QCA) analysis software named as medis suite XA/QAngio XA (Medis, Leiden, The Netherlands) (Figure 1). The software LMCA-LAD, LMCA-CX and LAD-CX bifurcation angles and these were measured at left anterior oblique $-50^{\circ}$ projection with $30^{\circ}$ caudal angulation and right anterior oblique $-30^{\circ}$ projection with $20^{\circ}$ caudal angulation. The mean values of three consecutive measurements were taken. All angiograms were interpreted by the consensus of two interventional cardiologists who were blinded to the patients' clinical and laboratory data. Intra-observer and inter-observer coefficients of variations for the measurement of bifurcation angle were found to be $1.2 \%$ and $1.7 \%$, respectively.

\section{Statistical Analysis}

Data were analyzed with the IBM SPSS Statistics for Windows, Version 24.0 (IBM Corp., Armonk, NY, USA). In this study, data are expressed as mean (standard deviation) for continuous variables and as counts and percentages for categorical variables. The Kolmogorov-Smirnov's and Shapiro-Wilk test were used to evaluate the distribution of continuous variables. The $\chi^{2}$ test and Fisher's Exact test were used to analyze categorical variables. The Student's t-test was used for continuous variables with normal distribution including LAD-CX bifurcation angle values and the values were presented as mean (standard deviation). Numerical variables not showing normal distribution were expressed as median (interquartile range), and categorical variables as percentages (\%). Comparison of intergroup continuous variables without normal distribution was analyzed using the Mann-Whitney $U$ test. The effect of various variables on no-reflow was calculated by univariate regression analysis. In these analyses, variables with unadjusted $\mathrm{p}<0.05$ were identified as confounding factors and were included in multivariate regression analyses to determine the independent predictors of no-reflow. The predictive value for no-reflow related to bifurcation angle was estimated by using receiver operating characteristic curve (ROC) and Youden index [maximum (sensitivity + specificity -1)]. A 2-tailed $p$-value of $<0.05$ was considered statistically significant.

\section{Results}

Baseline demographic and clinical characteristics of patients with no-reflow and normal flow are shown in Table 1. The mean age of our study group was 64.2 (10.8) years and 161 (80.5\%) patients of our study group were male. Patients with no-reflow had a higher prevalence of hypertension and diabetes mellitus (DM) compared to patients with normal flow ( $62.5 \%$ vs. $30.0 \%$ and $40.0 \%$ vs. $16.3 \%, \mathrm{p}<0.001$ ). In addition, serum C-reactive protein (CRP) levels were higher in the no-reflow group when compared to patients in the normal flow group $(13.2 \mathrm{mg} / \mathrm{dL}$ vs. 3.3 $\mathrm{mg} / \mathrm{dL}, \mathrm{p}<0.001)$. On the other hand, serum hemoglobin levels were significantly lower in the no-reflow group when compared to the normal flow group [13.49 (2.06) g/ dL vs. 14.50 (1.91) g/dL, p<0.001]. Other demographic and clinical variables were not significantly different between 


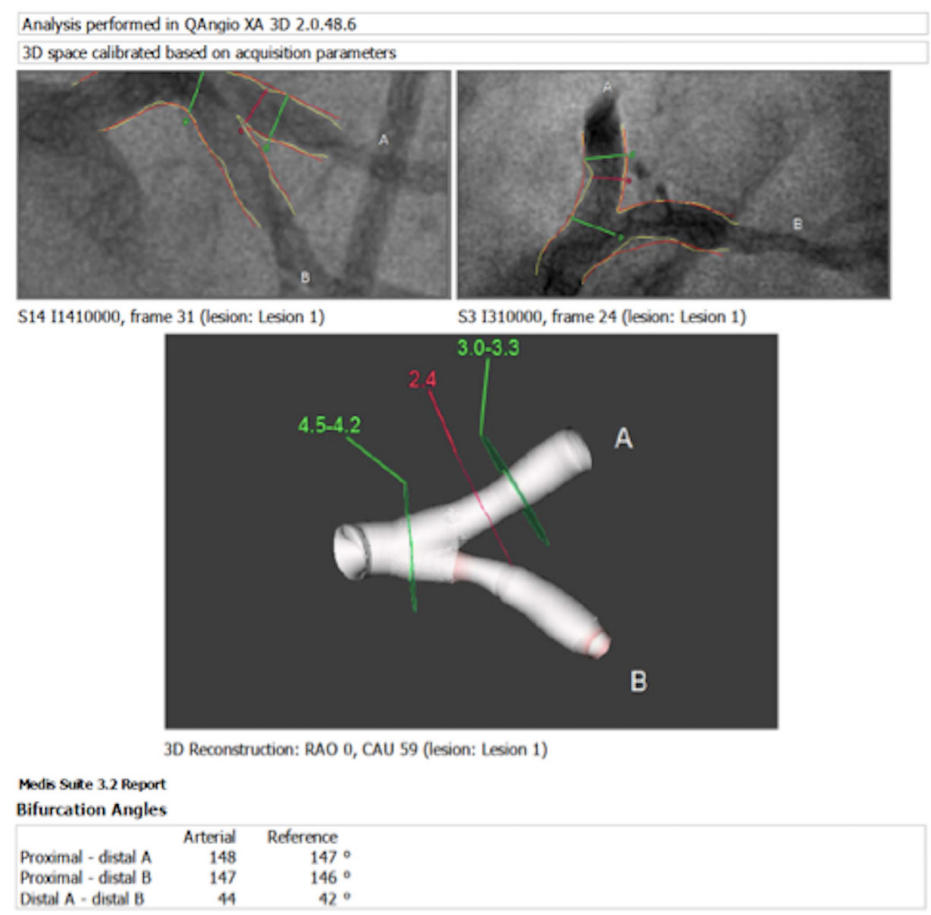

Figure 1. Figure shows an example of measurements for bifurcation angles in 3D software. Vessel B stands for left anterior descending artery and vessel A stands for circumflex artery. Proximal-distal A stands for angle between left main coronary artery and circumflex artery, proximal-distal B stands for angle between left main coronary artery and left anterior descending artery and distal A-distal B stands for angle between left anterior descending artery and circumflex artery

Table 1. Demographic, clinical and laboratory characteristics of the patients

\begin{tabular}{|c|c|c|c|c|}
\hline & $\begin{array}{l}\text { All patients } \\
(n=200)\end{array}$ & $\begin{array}{l}\text { No-reflow (-) } \\
(n=80)\end{array}$ & $\begin{array}{l}\text { No-reflow }(+) \\
(n=120)\end{array}$ & $\mathbf{p}$ \\
\hline Age, years & $64.2(10.8)$ & $63.7(9.3)$ & $64.5(11.7)$ & 0.598 \\
\hline Male, n (\%) & $161(80.5 \%)$ & $68(85.0 \%)$ & $93(77.5 \%)$ & 0.190 \\
\hline LV ejection fraction, \% & $43.0(9.5)$ & $43.0(10.0)$ & $43.1(9.3)$ & 0.928 \\
\hline Smoking status, n (\%) & 87 (43.5\%) & $38(47.5 \%)$ & 49 (40.8\%) & 0.352 \\
\hline Hypertension, n (\%) & 99 (49.5\%) & $24(30.0 \%)$ & 75 (62.5\%) & $<0.001$ \\
\hline Diabetes mellitus, n (\%) & $61(30.5 \%)$ & $13(16.3 \%)$ & $48(40.0 \%)$ & $<0.001$ \\
\hline COPD, n (\%) & $15(7.5 \%)$ & $5(6.3 \%)$ & $10(8.3 \%)$ & 0.584 \\
\hline $\mathrm{GFR}, \mathrm{mL} / \mathrm{min}$ & $86.6(27.6)$ & $85.8(20.1)$ & $87.3(31.7)$ & 0.707 \\
\hline Creatinine, $\mathrm{mg} / \mathrm{dL}$ & $0.90(0.78-1.10)$ & $0.94(0.80-1.07)$ & $0.90(0.74-1.10)$ & 0.353 \\
\hline C-reactive protein, $\mathrm{mg} / \mathrm{dL}$ & $4.5(2.2-22.1)$ & $3.3(1.8-7.5)$ & $13.2(3.8-52.7)$ & $<0.001$ \\
\hline Total cholesterol, mg/dL & $194(41)$ & $200(35)$ & $189(45)$ & 0.087 \\
\hline $\mathrm{LDL}, \mathrm{mg} / \mathrm{dL}$ & $120(36)$ & $123(33)$ & $117(38)$ & 0.341 \\
\hline $\mathrm{HDL}, \mathrm{mg} / \mathrm{dL}$ & $40.5(10.5)$ & $40.6(9.2)$ & $40.5(11.4)$ & 0.942 \\
\hline Triglyceride, mg/dL & $140(107-209)$ & $161(115-209)$ & $129(97-207)$ & 0.054 \\
\hline White blood cells, $10^{3} / \mathrm{uL}$ & $11.10(8.43-13.94)$ & $11.15(8.35-13.81)$ & $10.94(8.43-14.22)$ & 0.842 \\
\hline Hemoglobin, g/dL & $13.91(2.05)$ & $14.50(1.91)$ & $13.49(2.06)$ & 0.001 \\
\hline Platelet, $10^{3} / \mathrm{uL}$ & $263(75)$ & $267(71)$ & $261(78)$ & 0.540 \\
\hline Neutrophil, $10^{3} / \mathrm{uL}$ & $7.25(4.93-11.15)$ & $6.99(4.72-8.94)$ & $7.81(5.11-11.52)$ & 0.215 \\
\hline Lymphocyte, $10^{3} /$ uL & $2.10(1.44-2.89)$ & $2.22(1.50-3.32)$ & $2.05(1.43-2.80)$ & 0.134 \\
\hline
\end{tabular}

LV: Left ventricle, GFR: Glomerular filtration rate, COPD: Chronic obstructive pulmonary disease, LDL: Low-density lipoprotein, HDL: High-density lipoprotein, MPV: Mean platelet volume 
Table 2. Angiographic characteristics of the patients

\begin{tabular}{|c|c|c|c|c|}
\hline & $\begin{array}{l}\text { All patients } \\
(n=200)\end{array}$ & $\begin{array}{l}\text { No-reflow (-) } \\
(n=80)\end{array}$ & $\begin{array}{l}\text { No-reflow }(+) \\
(n=120)\end{array}$ & $\mathbf{p}$ \\
\hline LAD lesion, n (\%) & $155(77.5 \%)$ & $58(72.5 \%)$ & $97(80.8 \%)$ & 0.167 \\
\hline CX lesion, n (\%) & $45(22.5 \%)$ & $22(27.5 \%)$ & $23(19.2 \%)$ & 0.167 \\
\hline Pre TIMI score & & & & 0.259 \\
\hline $0, \mathrm{n}(\%)$ & $129(64.5 \%)$ & $50(62.5 \%)$ & $79(65.8 \%)$ & \\
\hline $1, \mathrm{n}(\%)$ & $36(18.0 \%)$ & $19(23.8 \%)$ & $17(14.2 \%)$ & \\
\hline $2, \mathrm{n}(\%)$ & $34(17.0 \%)$ & $11(13.8 \%)$ & $23(19.2 \%)$ & \\
\hline $3, \mathrm{n}(\%)$ & $1(0.5 \%)$ & $0(0.0 \%)$ & $1(0.8 \%)$ & \\
\hline Post TIMI score & & & & $<0.001$ \\
\hline $0, \mathrm{n}(\%)$ & $48(24.0 \%)$ & $0(0.0 \%)$ & $48(40.0 \%)$ & \\
\hline $1, \mathrm{n}(\%)$ & $71(35.5 \%)$ & $0(0.0 \%)$ & $71(59.2 \%)$ & \\
\hline $2, \mathrm{n}(\%)$ & $1(0.5 \%)$ & $0(0.0 \%)$ & $1(0.8 \%)$ & \\
\hline $3, \mathrm{n}(\%)$ & $80(40 \%)$ & $80(100 \%)$ & $0(0.0 \%)$ & \\
\hline LMCA length, mm & $14.4(11.1-17.8)$ & $14.0(10.8-17.8)$ & $14.9(11.6-17.8)$ & 0.507 \\
\hline LMCA-LAD bifurcation angle, ${ }^{\circ}$ & $123.0(14.9)$ & $124.8(12.2)$ & $121.7(16.5)$ & 0.147 \\
\hline LMCA-CX bifurcation angle, ${ }^{\circ}$ & $128.1(17.7)$ & $130.8(18.1)$ & $126.4(17.2)$ & 0.083 \\
\hline LAD-CX bifurcation angle, ${ }^{\circ}$ & $100.9(23.1)$ & $85.9(15.8)$ & $110.9(21.8)$ & $<0.001$ \\
\hline Lesion length, mm & $21.0(3.5)$ & $20.7(3.3)$ & $21.2(3.6)$ & 0.364 \\
\hline Reference vessel diameter, $\mathrm{mm}$ & $2.94(0.26)$ & $2.96(0.27)$ & $2.93(0.25)$ & 0.478 \\
\hline
\end{tabular}

LAD: Left anterior descending artery, CX: Circumflex artery, LMCA: Left main coronary artery

Table 3. Logistic regression analyses for investigation of independent correlates for no-reflow after PCI

\begin{tabular}{|c|c|c|c|c|}
\hline & Univariate analysis & & Multivariate analys & \\
\hline & OR $(95 \% \mathrm{Cl})$ & $\mathbf{p}$ & OR $(95 \% \mathrm{Cl})$ & $\mathbf{p}$ \\
\hline Hypertension & $3.889(2.125-7.117)$ & $<0.001$ & $7.268(2.588-20.406)$ & $<0.001$ \\
\hline C-reactive protein & $1.020(1.007-1.032)$ & 0.002 & $1.009(0.993-1.025)$ & 0.28 \\
\hline Hemoglobin & $0.771(0.660-0.900)$ & 0.001 & $0.871(0.667-1.138)$ & 0.31 \\
\hline
\end{tabular}

OR: Odds ratio, LAD: Left anterior descending artery, CX: Circumflex artery, Cl: Confidence interval, PCl: Percutaneous coronary intervention

both groups. The angiographic characteristics are shown in Table 2. The no-reflow and normal flow groups were similar in terms of culprit vessels involved and total LMCA length. LAD lesions were dominant in both groups. Calculated bifurcation angle of the LAD-CX was significantly wider in the no-reflow group when compared to the normal flow group $\left[110.9^{\circ}\left(21.8^{\circ}\right)\right.$ vs. $\left.85.9^{\circ}\left(15.8^{\circ}\right), \mathrm{p}<0.001\right]$. However, there was no significant difference between the groups in terms of reference vessel diameter and lesion length.

Univariate and multivariate regression analysis for noreflow are shown in Table 3. Multivariate analyses showed that history of hypertension and LAD-CX bifurcation angle were significantly associated with no-reflow phenomenon $(\mathrm{p}<0.001)$ (Figure 2). Additionally, hemoglobin levels were analyzed according to gender in the study population
(Table 4). In females, there was no significant difference in terms of hemoglobin levels and coronary no re-flow; however, in males, there was a significant difference in terms of hemoglobin levels and coronary no re-flow. Male patients who had coronary no re-flow had lower levels of hemoglobin when compared to the male patients without coronary no-reflow.

ROC analysis was performed to detect the optimal cutoff value for LAD-CX bifurcation angle in predicting the occurrence of no-reflow phenomenon. Bifurcation angle $\geq 98.1^{\circ}$ predicted the occurrence of no-reflow phenomenon (Table 5, Figure 3). In the no-reflow group, $79.2 \%$ of the patients had LAD-CX bifurcation angle $\geq 98.1^{\circ}$ and in contrast to that, $20.8 \%$ patients had LAD-CX bifurcation angle $<98.1^{\circ}$ (Figure 4). Additionally, CRP levels and hemoglobin levels were analyzed in ROC analysis to detect 


\begin{tabular}{|c|c|c|c|c|c|c|}
\hline & Female & & & Male & & \\
\hline & $\begin{array}{l}\text { No-reflow (-) } \\
(n=12)\end{array}$ & $\begin{array}{l}\text { No-reflow }(+) \\
(n=27)\end{array}$ & $\mathbf{p}$ & $\begin{array}{l}\text { No-reflow (-) } \\
(n=68)\end{array}$ & $\begin{array}{l}\text { No-reflow }(+) \\
(n=89)\end{array}$ & $\mathbf{p}$ \\
\hline Hemoglobin, g/dL & $12.20 \pm 1.87$ & $14.42 \pm 1.71$ & 0.715 & $14.91 \pm 1.61$ & $13.82 \pm 2.05$ & $<0.001$ \\
\hline
\end{tabular}

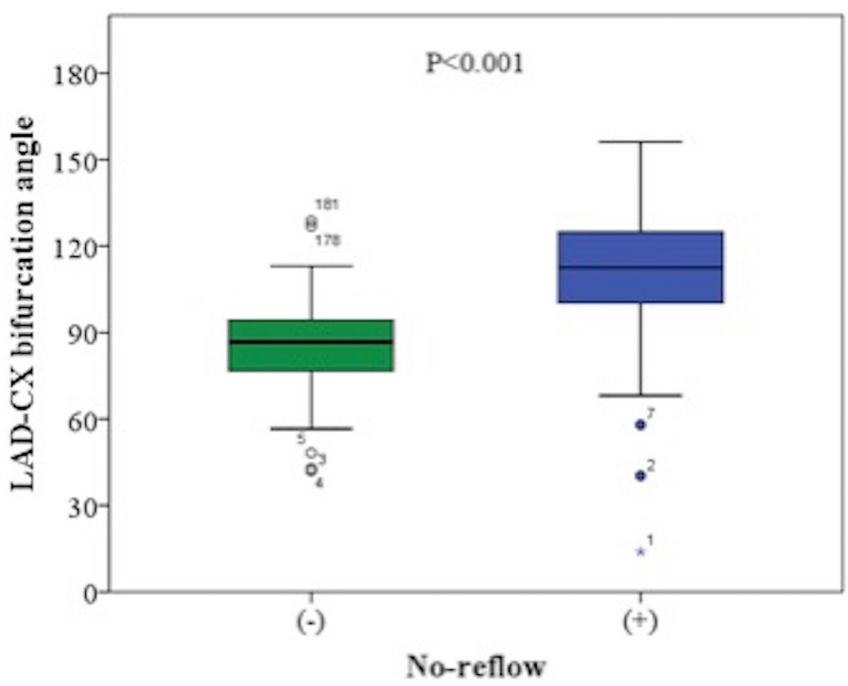

Figure 2. Figure shows the difference of left anterior descending artery-circumflex artery bifurcation angles between the two groups. The box plot provides the non-outlier minimum value, the first $(25 \%)$ quarter, the median value, the third quarter $(75 \%)$, and the nonoutlier maximum value of the bifurcation angle. The dots indicate outliers

a cut-off value, and CRP level higher than $10.0 \mathrm{mg} / \mathrm{dL}$ and hemoglobin level less than $14.1 \mathrm{~g} / \mathrm{dL}$ were found to be associated with no-reflow during PCI of STEMI patients.

\section{Discussion}

In the present study, we evaluated the association between bifurcation angle and development of noreflow phenomenon in patients with STEMI treated with primary PCI. We found that bifurcation angle was a strong predictor for no-reflow phenomenon when compared to other parameters. To the best of our knowledge, this is the first study in literature, which evaluates the relationship between bifurcation angle and occurrence of no-reflow following primary PCI.

The no-reflow phenomenon is frequently observed during PCI and associated with various adverse cardiac events including left ventricular dysfunction, malignant arrhythmias, cardiogenic shock or death $(11,13)$. According to a meta-analysis conducted by Fajar et al. (22), advanced age, male sex, family history of coronary artery disease, smoking, DM, hypertension, delayed reperfusion, higher Killip class at admission, elevated blood glucose, elevated creatinine, collateral flow, lesion length, multivessel disease, reference luminal diameter, initial TIMI flow, and high thrombus burden were proven to be associated with the development of no-reflow phenomenon following primary PCI. The underlying pathophysiologic mechanism, which contributes to the development of no-reflow, is mostly related to the association between parameters mentioned above and endothelial dysfunction and neurohumoral activation (22). Despite various known risk factors, it is still a challenge to predict the development of no-reflow in STEMI patients who underwent primary PCI. In our study, in contrast to previous studies, there was no significant difference between the groups in terms of lesion length, reference vessel diameter, advanced age, gender, and ejection fraction. On the other hand, DM, hypertension, higher serum CRP levels, lower serum hemoglobin levels and LAD-CX bifurcation angle were significantly associated with coronary no-reflow in univariate analysis. However, only hypertension and LAD-CX bifurcation angle were remained as independent predictors of noreflow on multivariate analysis.

Recent studies in which investigated hemodynamics of coronary bifurcations by using computational fluid dynamics have demonstrated a close relationship between arterial hemodynamics and vascular geometry $(23,24)$. Chiastra et al. (25) demonstrated that altered hemodynamics in all bifurcation regions led to a significant decrease in secondary flow of side branches. Not only vascular geometry of bifurcation site but also bifurcation angle resulted in recirculation and counter rotating helical flow. If the angle was wide, helical flows were found to be more evident. As a result of these alterations in fluid dynamics, decreased intravascular pressure and increased resistance in the arterial wall would be observed. Accordingly, this pressure-flow relationship was more pronounced when there was a significant side branch occlusion (25).

Studies also demonstrated a strong association between endothelial dysfunction and disturbed vascular flow due to wide angulation of vascular tree (26-28). Furthermore, it has been shown that shear stress in arterial wall and 


\begin{tabular}{llllll} 
& Sensitivity & Specificity & PPV & NPV & Accuracy \\
\hline LAD-CX bifurcation angle $\geq 98.1$ & $79.2 \%$ & $81.2 \%$ & $86.4 \%$ & $72.2 \%$ & $80.0 \%$ \\
\hline
\end{tabular}

PPV: Positive predictive value, NPV: Negative predictive value, LAD: Left anterior descending artery, CX: Circumflex artery, ROC: Receiver operating characteristic curve

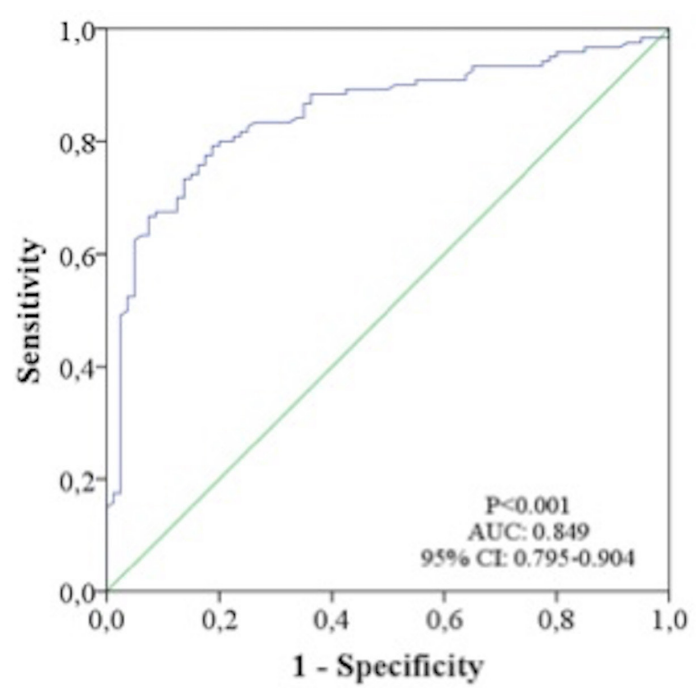

Figure 3. Receiver operating curve analysis showed the optimal cut-off value for left anterior descending arterycircumflex artery bifurcation angle in predicting noreflow

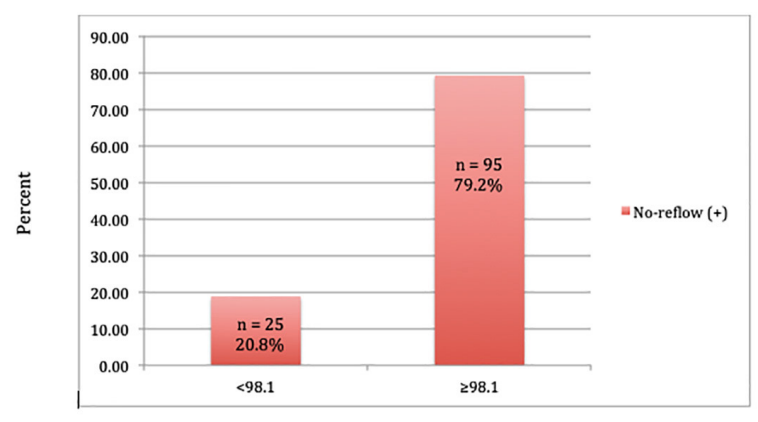

Left Anterior Descending Artery - Circumflex Artery Bifurcation Angle

Figure 4. Figure shows, in the control group, $81.3 \%$ of the patients had left anterior descending artery-circumflex artery bifurcation angle $<98.1$ degrees and in the noreflow (+) group, $79.2 \%$ of the patients had left anterior descending artery-circumflex artery bifurcation angle $\geq 98.1$ degrees

disturbed blood flow in wide-angle bifurcations may contribute to the development of atherosclerosis as a result of endothelial dysfunction. Hemodynamic environment in the vascular tree is complicated because the geometric structure of vascular tree might be in different morphologies such as straight, curved, branched, converged and diverged. When a segment of an artery is straight, the hemodynamic flow pattern is typically laminar and wall shear stress is high and directed; however, in the curved, branched and diverged regions of arterial segments, the hemodynamic flow becomes disturbed with non-laminar and irregular distribution of low wall shear stress (18). Changes in hemodynamic forces might trigger complex and multiple signaling physiologic cascades that initiate mechanotransduction. This mechanotransduction process generates biochemical signals which results in changes in endothelial dysfunction and alterations in vascular behavior $(29,30)$.

In our study, the estimated mean LAD-CX bifurcation angle was $85.9^{\circ}\left(15.8^{\circ}\right)$ in patients with normal flow which, was compatible with the outcomes of previous studies. According to a study conducted by Rodriguez-Granillo et al. (31), reported mean LAD-CX bifurcation angle was $88.5^{\circ}$. In another postmortem study, which consisted of 100 patients, Reig and Petit (32) reported a mean LAD-CX bifurcation angle of $86.7^{\circ}\left(28.8^{\circ}\right)$. Additionally, estimated LAD-CX bifurcation angle in patients with no-reflow phenomenon was $110.9^{\circ}\left(21.8^{\circ}\right)$. Our data suggested that bifurcation angle of LAD-CX showed a significant correlation with the development of noreflow phenomenon. We hypothesize that the strong association between widely angulated left sided coronary artery bifurcations and low wall shear stress yields to disturbances of bloodstream, which contributes to the development of no reflow. We also speculate that this might be due to endothelial dysfunction that is a leading cause of coronary no-reflow.

\section{Study Limitations}

In this study, there are some limitations that should be acknowledged. First, the study design is retrospective and the number of cases who developed no-reflow following primary PCI is relatively small. Second, we only focused on bifurcation angles of the LMCA-LAD, LMCA-CX and LADCX in this study, while excluding other types of bifurcation subgroups including LAD- diagonal artery, CX-obtus marginalis and posterior descending artery-posterolateral artery. In addition, the results of this study need to be interpreted with caution with regard to diagnostic value of QCA measurements for evaluating bifurcation angles. Further studies with inclusion of more cases and all 
subgroups of bifurcation angles by using more accurate techniques are desirable.

\section{Conclusion}

We conclude that measurement of bifurcation angles of LAD-CX could be a useful tool for predicting no-reflow phenomenon in STEMI patients who underwent primary PCI. This novel method not only allows earlier detection of STEMI patients with high risk of no-reflow but also helps to choose the best treatment. Since the causes of coronary no-reflow are multifactorial and there is lack of optimal treatment strategy for this phenomenon, it is mandatory to prevent the development of no-reflow. This study may provide a clinically useful approach in terms of investigating the predictive role of bifurcation angle for the development of coronary no-reflow.

\section{Ethics}

Ethics Committee Approval: Ethical approvement was retrieved from University of Health Sciences Turkey, İstanbul Mehmet Akif Ersoy Thoracic and Cardiovascular Surgery Training and Research Hospital (date: 22.12.2020, no: 2020/82) Local Ethical Committee for the study.

Informed Consent: Informed consent was obtained.

Peer-review: Externally peer-reviewed.

\section{Authorship Contributions}

Concept: Ö.T., R.G., M.D., Design: Ö.T., R.G., M.D., Data Acqusition: Ö.T., R.G., M.D., A.R.D., Data Analysis/ Interpretation: Ö.T., A.A.Ş., A.R.D., Drafting Manuscript: A.A.Ş., Ö.T., M.D., Critical Revision of Manuscript: A.A.Ş., M.E., M.E.K., A.R.D., Final Approval and Accountability: A.A.Ş., Ö.T., M.E.K., M.E., Technical or Material Support: Ö.T., M.E., M.E.K., R.G.

Conflict of Interest: No conflict of interest was declared by the authors.

Financial Disclosure: The author declared that this study has received no financial support.

\section{References}

1. Task Force on the management of ST-segment elevation acute myocardial infarction of the European Society of Cardiology (ESC), Steg PG, James SK, Atar D, Badano LP, Blömstrom-Lundqvist C, et al. ESC Guidelines for the management of acute myocardial infarction in patients presenting with ST-segment elevation. Eur Heart J 2012;33(20):2569-2619.

2. Hagen TP, Häkkinen U, Belicza E, Fatore G, Goude F; EuroHOPE study group. Acute myocardial infarction, use of percutaneous coronary intervention, and mortality: a comparative effectiveness analysis covering seven European countries. Health Econ 2015;24(Suppl 2):88-101.

3. Choo EH, Kim PJ, Chang K, Ahn Y, Jeon DS, Lee JM, et al. The impact of no-reflow phenomena after primary percutaneous coronary intervention: a time-dependent analysis of mortality. Coron Artery Dis 2014;25(5):392-398.

4. Kelly RV, Cohen MG, Stouffer GA. Incidence and management of "no-reflow" following percutaneous coronary interventions. Am J Med Sci 2005;329(2):78-85.

5. Jaffe R, Charron T, Puley G, Dick A, Strauss BH. Microvascular obstruction and the no-reflow phenomenon after percutaneous coronary intervention. Circulation 2008;117(24):3152-3156.

6. Wang L, Cheng Z, Gu Y, Peng D. Short-term effects of verapamil and diltiazem in the treatment of no reflow phenomenon: a meta-analysis of randomized controlled trials. Biomed Res Int 2015;2015:382086.

7. Abu Arab T, Rafik R, El Etriby A. Efficacy and safety of local intracoronary drug delivery in treatment of no-reflow phenomenon: a pilot study. J Interv Cardiol 2016;29(5):496-504.

8. Mazhar J, Mashicharan M, Farshid A. Predictors and outcome of no-reflow post primary percutaneous coronary intervention for ST elevation myocardial infarction. Int J Cardiol Heart Vasc 2015;10:8-12.

9. Berg R, Buhari C. Treating and preventing no reflow in the cardiac catheterization laboratory. Curr Cardiol Rev 2012;8(3):209-214.

10. Gupta S, Gupta MM. No reflow phenomenon in percutaneous coronary interventions in ST-segment elevation myocardial infarction. Indian Heart J 2016;68(4):539-551.

11. Ramjane K, Han L, Jin C. The diagnosis and treatment of the no-reflow phenomenon in patients with myocardial infarction undergoing percutaneous coronary intervention. Exp Clin Cardiol 2008;13(3):121-128.

12. Choo E. Long-term prognostic impact of no-reflow phenomenon after primary percutaneous coronary intervention in patients with St-segment elevation myocardial infarction. Circulation 2013;1288(Suppl 22):A15199.

13. Wong DT, Puri R, Richardson JD, Worthley MI, Worthley SG. Myocardial 'no-reflow'-diagnosis, pathophysiology and treatment. Int J Cardiol 2013;167(5):1798-1806.

14. Ndrepepa G, Tiroch K, Keta D, Fusaro M, Seyfarth M, Pache J, et al. Predictive factors and impact of no reflow after primary percutaneous coronary intervention in patients with acute myocardial infarction. Circ Cardiovasc Interv 2010;3(1):27-33.

15. Napodano M, Ramondo A, Tarantini G, Peluso D, Compagno S, Fraccaro C, et al. Predictors and time-related impact of distal embolization during primary angioplasty. Eur Heart J 2009;30(3):305-313.

16. Mongrain R, Rodés-Cabau J. Papel. de la tensión de cizallamiento en la enfermedad aterosclerótica y la reestenosis tras implantación de stent coronario [Role of shear stress in atherosclerosis and restenosis after coronary stent implantation]. Rev Esp Cardiol 2006;59(1):1-4.

17. Sun Z, Chaichana T. Computational fluid dynamic analysis of calcified coronary plaques: correlation between hemodynamic changes and cardiac image analysis based on left coronary bifurcation angle and lumen assessments. Interv Cardiol 2016;8(6):713-719. 
18. Chiu JJ, Chien S. Effects of disturbed flow on vascular endothelium: pathophysiological basis and clinical perspectives. Physiol Rev 2011;91(1):327-387.

19. Ibanez B, James S, Agewall S, Antunes MJ, Bucciarelli-Ducci C, Bueno H, et al; ESC Scientific Document Group. 2017 ESC Guidelines for the management of acute myocardial infarction in patients presenting with ST-segment elevation: The Task Force for the management of acute myocardial infarction in patients presenting with ST-segment elevation of the European Society of Cardiology (ESC). Eur Heart J 2018;39(2):119-177.

20. Gibson CM, Schömig A. Coronary and myocardial angiography: angiographic assessment of both epicardial and myocardial perfusion. Circulation 2004;109(25):3096-3105.

21. van't Hof AW, Liem A, Suryapranata H, Hoorntje JC, de Boer MJ, Zijlstra F. Angiographic assessment of myocardial reperfusion in patients treated with primary angioplasty for acute myocardial infarction: myocardial blush grade. Zwolle Myocardial Infarction Study Group. Circulation 1998;97(23):2302-2306.

22. Fajar JK, Heriansyah T, Rohman MS. The predictors of no reflow phenomenon after percutaneous coronary intervention in patients with ST elevation myocardial infarction: A meta-analysis. Indian Heart J 2018;70(Suppl 3):S406-S418.

23. Morbiducci U, Kok AM, Kwak BR, Stone PH, Steinman DA, Wentzel JJ. Atherosclerosis at arterial bifurcations: evidence for the role of haemodynamics and geometry. Thromb Haemost 2016;115(3):484492.

24. Malvè M, Gharib AM, Yazdani SK, Finet G, Martínez MA, Pettigrew $\mathrm{R}$, et al. Tortuosity of coronary bifurcation as a potential local risk factor for atherosclerosis: CFD steady state study based on in vivo dynamic CT measurements. Ann Biomed Eng 2015;43(1):82-93.
25. Chiastra C, Iannaccone F, Grundeken MJ, Gijsen FJ, Segers P, De Beule $\mathrm{M}$, et al. Coronary fractional flow reserve measurements of a stenosed side branch: a computational study investigating the influence of the bifurcation angle. Biomed Eng Online 2016;15(1):91.

26. Libby P. Inflammation in atherosclerosis. Nature 2002;420(6917):868-874.

27. Davignon J, Ganz P. Role of endothelial dysfunction in atherosclerosis. Circulation 2004;109(23 Suppl 1):III27-III32.

28. Plank MJ, Wall DJ, David T. Atherosclerosis and calcium signalling in endothelial cells. Prog Biophys Mol Biol 2006;91(3):287-313.

29. Berk BC. Atheroprotective signaling mechanisms activated by steady laminar flow in endothelial cells. Circulation 2008;117(8):1082-1089.

30. Chien S. Mechanotransduction and endothelial cell homeostasis: the wisdom of the cell. Am J Physiol Heart Circ Physiol 2007;292(3):H1209-H12024.

31. Rodriguez-Granillo GA, Rosales MA, Degrossi E, Durbano I, Rodriguez AE. Multislice CT coronary angiography for the detection of burden, morphology and distribution of atherosclerotic plaques in the left main bifurcation. Int J Cardiovasc Imaging 2007;23(3):389-392.

32. Reig J, Petit M. Main trunk of the left coronary artery: anatomic study of the parameters of clinical interest. Clin Anat 2004;17(1):613. 